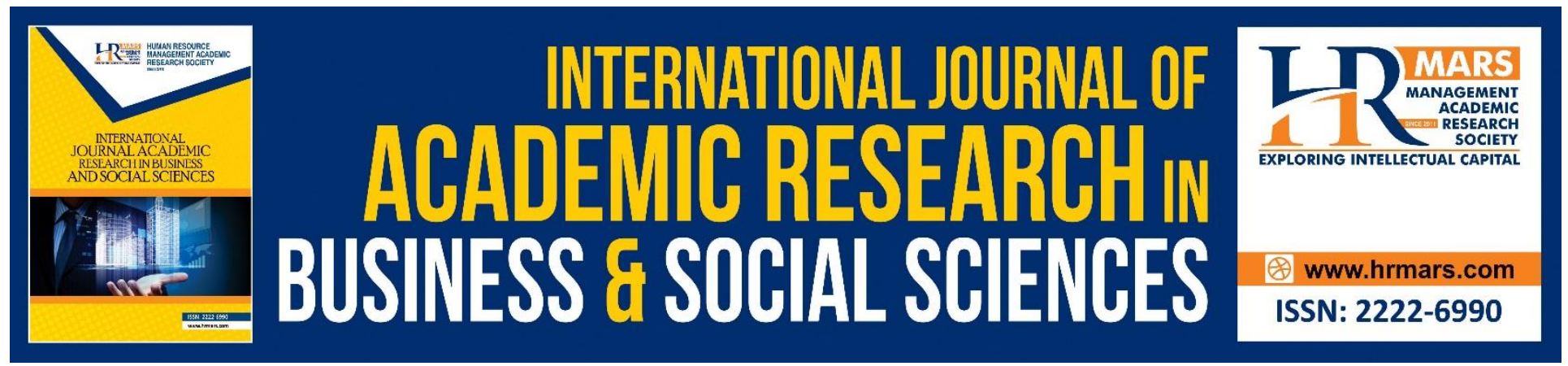

\title{
Validity of Teamwork Instruments in the TIG Welding Training Modules based on Project Based Learning (PBP)
}

\author{
Md Kharul Bin Rakib, Che Ghani bin Che Kob, Arman Shah \& Arasinah
}

To Link this Article: http://dx.doi.org/10.6007/IJARBSS/v9-i2/5614 DOI: $10.6007 /$ IJARBSS/v9-i2/5614

Received: 17 Jan 2019, Revised: 25 Feb 2019, Accepted: 10 March 2019

Published Online: 13 March 2019

In-Text Citation: (Rakib, Kob, Shah, \& Arasinah, 2019)

To Cite this Article: Rakib, M. K. Bin, Kob, C. G. bin C., Shah, A., \& Arasinah. (2019). Validity of Teamwork Instruments in the TIG Welding Training Modules based on Project Based Learning (PBP). International Journal of Academic Research in Business and Social Sciences, 9(2), 774-781.

\section{Copyright: (C) 2019 The Author(s)}

Published by Human Resource Management Academic Research Society (www.hrmars.com)

This article is published under the Creative Commons Attribution (CC BY 4.0) license. Anyone may reproduce, distribute, translate and create derivative works of this article (for both commercial and non-commercial purposes), subject to full attribution to the original publication and authors. The full terms of this license may be seen

at: http://creativecommons.org/licences/by/4.0/legalcode

Vol. 9, No. 2, 2019, Pg. 774 - 781

http://hrmars.com/index.php/pages/detail/IJARBSS

JOURNAL HOMEPAGE

Full Terms \& Conditions of access and use can be found at http://hrmars.com/index.php/pages/detail/publication-ethics 


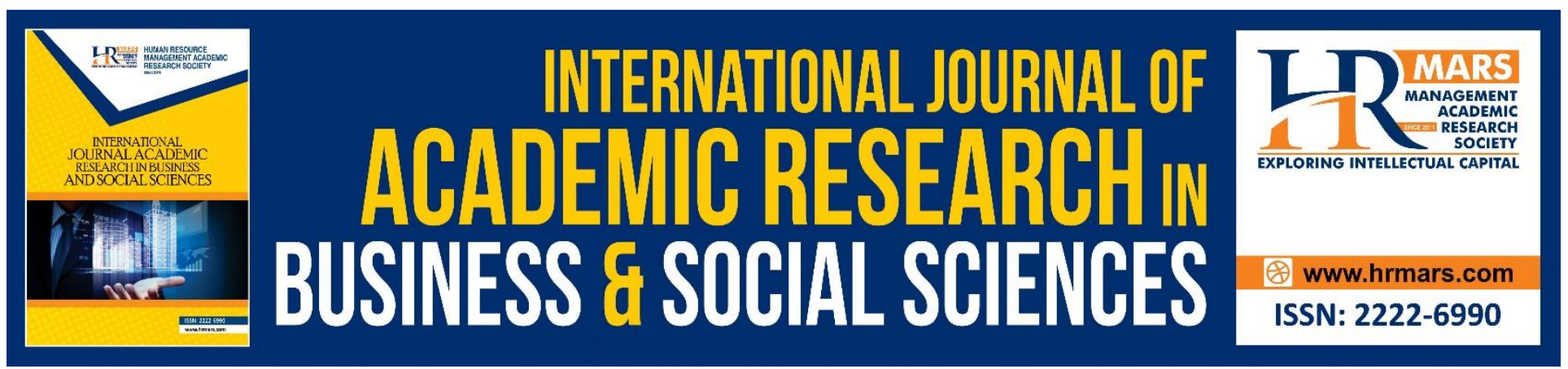

\title{
Validity of Teamwork Instruments in the TIG Welding Training Modules
}

\author{
Md Kharul Bin Rakib, Che Ghani bin Che Kob, Arman Shah \& \\ Arasinah \\ Universiti Pendidikan Sultan Idris (UPSI) \\ Email: mdkharul87@gmail.com
}

\begin{abstract}
This study is aimed at the validity of a teamwork questionnaire in the TIG Welding Training Module based on Project Based Learning (PBP) in the Subject (DJJ3032) of Mechanical Workshop Practice 3 at Polytechnic Malaysia. This study was quantified using the survey method to get an expert opinion through a questionnaire related to the content of the teamwork instrument. The research sample consists of 8 experts who are experienced in the field of welding in Malaysia. The findings show that this research instrument has a high content validity. The findings of the validity of the content of a team workforce demonstrate the contents of this instrument are valid and of good quality and can be applied. It is hoped that a teamwork workforce in TIG Welding Training Modules will enhance the achievement of polytechnic students in turn to create human capital that will become the catalyst for future development.
\end{abstract}

Keywords: Validity, Questionnaire Instrument, Teamwork

\section{Introduction}

The purpose of this study was to validate the teamwork questionnaire instrument in the TIG Welding Module based on Project Based Learning (PBP) in the subject (DJJ3032) of the Mechanical Workshop Practice 3 at Polytechnic Malaysia.

In the midst of this modernization, teamwork skills are the skills needed by every graduate to help them compete for jobs in local or international markets (Yulpisman, 2006 \& Noor, 2010). Among the latest issues are still available among Vocational students or TVET who have not mastered good teamwork (Idris, 2012). Meanwhile, according to the study of Badarudin et al. (2010) which summarizes the case of graduates failing to get their jobs today is due to the lack of teamwork skills. In addition, some students also have negative attitudes towards teamwork and refuse to work in a team because they consider teamwork as a workplace inequality that creates tensions, conflicts and unmotivated and student emotions will gradually become negative at the end of the project or learning (Peslak, 2005; Sundrum \& Kanasan, 2013). Meanwhile, according to DiFonzo (2010) study, employers are not only looking for experienced workers, but also looking for workers who can work 
effectively in teams and understand how the management process works. This is because according to Ohland et al.,(2010) found that the complexity of a project that took place at the project site was not due to the complexity of the project, but its main problem was that people who did the project themselves lack the skills to work in teams. In addition, according to the study of Mohd Salleh, Sulaiman and Talib (2010) also have the same finding that the current curriculum development is less emphasis on teamwork and is too specific to academic achievement. This illustrates the importance of teamwork in producing high-quality human capital.

\section{Research Objective}

Validity of the teamwork questionnaire instrument in the TIG Welding Training Modules based on the Project Based Learning (PBP) on the subject (DJJ3032) of the Mechanical Workshop Practice 3 in Polytechnic Malaysia.

\section{Methodology}

This study was quantified using a survey method to identify the validity of the content of the teamwork instrument in the TIG Welding Training Module. Additionally, the instrument developed, needs to be reviewed by the field expert to obtain the validity of the instrument contents in this study, the researcher conducts the validity of the content of the teamwork instrument to ensure that the contents of the instrument are properly crafted and recognized quality.

The use of validity in the study is to test the extent to which the accuracy of a measuring instrument studied in a study. According to Pallant (2007), validity refers to the extent to which a tool used to accurately measure the characteristics studied in a study. This implies that an instrument is considered to be valid and can be applied if it can measure what is supposed to be measured and an instrument or instrument of measurement is also valid when the construction of the tool meets or meets its function and objectives.

Meanwhile, according to Othman and Kassim (2018), the validity process is a marker for the accuracy of the study ie whether the study gives a true picture of the phenomenon studied or not. This validity process also needs to be done by individuals who are experts in the field related to the content of the questionnaire. This coincides with the statement of Idris (2013), stating that in order to increase the validity of the content of a research instrument, the researcher should seek views and feedback from the expert to evaluate and ensure the elements contained in an instrument represent the area of the study to be studied. This is because the feedback and views of these experts are very important for obtaining quality instruments that can be used.

For the validity of the instrument's content, according to Anastasi and Urbina (1997), the validity of the content is a systematic assessment of the quality of the content of an instrument that measures what is supposed to be measured. Additionally, to ensure that the built-in instrument is robust and applicable, the percentage of the instrument's validity should be considered. This is because of the high validity of the findings obtained based on facts and able to give correct justification (Idris, 2013).

The researcher has provided a complete copy of the TIG Welding Training Module which contains the introduction, objectives and objectives of the module, theoretical foundation used, the overall content and the attachment of teaching aids (ABBM). Teamwork questionnaire tools in TIG 
welding Training Modules are provided for review and evaluation and are provided by expert panels. The selection of expert groups in this study is based on expertise, experience and relevance with the contents of the instrument developed. In this study, the criteria for specialist selection are based on (i) expertise and knowledge in the field of TIG / GTAW welding. (ii) Expertise and experience in the field of welding (iii) expertise and experience in language (iv) experienced practitioners or welders and (v) Malaysian Polytechnic welding and casting book makers. Experienced practitioners or lecturers in the field of welding are further defined by ensuring that they understand and implement teaching and learning in Malaysian Polytechnic. The list of expert panels is like table 1 below.

Table 1: Expert Panel Profiles

\begin{tabular}{|c|c|}
\hline $\begin{array}{c}\text { Content } \\
\text { Specialist }\end{array}$ & Biodata And Experience \\
\hline \multirow[t]{2}{*}{ P1 } & * Malaysian Polytechnic Lecturer in welding \\
\hline & Teaching in the field of welding for 25 years until now \\
\hline \multirow[t]{3}{*}{$\mathbf{P 2}$} & - Malaysian Polytechnic Lecturer in welding field \\
\hline & - Experienced teaching welding approximately 10 years \\
\hline & - Has been a producer of welding courses at Community College \\
\hline \multirow[t]{3}{*}{ P3 } & \# Polytechnic lecturer in welding field \\
\hline & \# Teach welding workshops about 13 years \\
\hline & \# Experts in arc, gas, TIG and MIG welding bases since 2005 until now. \\
\hline \multirow[t]{5}{*}{ P4 } & - Welding lecturer in polytechnics \\
\hline & - Experienced welding work in the continental sime tire for 10 years and \\
\hline & teaching in welding field at Sarawak Polytechnic for 5 years and then \\
\hline & teaching at polytechnic in behrang for 4 years until now \\
\hline & - Experience in welding field for about 10 years. \\
\hline \multirow[t]{8}{*}{ P5 } & - Working as a welding advisor at JOTAC Academy \\
\hline & - Expertise in welding more than 40 years \\
\hline & - Experienced engineering engineer LTD in 1977 and worked with SIRIM in \\
\hline & 1980 and became UITM (mechanical faculty) lecturer in 2008. \\
\hline & $\begin{array}{l}\text { - Expertise in SMAW, GMAW, FCAW, GTAW, SAW, SW, welding consultant } \\
\text { and inospectery production of welding parameter and bend geometry for } \\
40 \text { years }\end{array}$ \\
\hline & - Approval of mechanical and master credentials in welding and CSWIP \\
\hline & - Issuance of 8 techical papers on GMAW, FCAW, SAW, FW \\
\hline & - Supervisor to 6 master students and 50 undergraduate students. \\
\hline \multirow[t]{4}{*}{ P6 } & $\circ$ Welding Lecturer at Malaysian Polytechnic \\
\hline & O Skills in Welding \\
\hline & $\circ$ Experience teaching welding for 7 years \\
\hline & $\bigcirc$ Experts in arc welding, MIG and TIG for 7 years \\
\hline \multirow[t]{4}{*}{ P7 } & $\checkmark \quad$ The Malaysian Polytechnic Welding Lecturer \\
\hline & $\checkmark$ Experience teaching welding (Arka, MIG and TIG) for 12 years \\
\hline & $\checkmark$ Expertise in arc welding, MIG and TIG \\
\hline & $\checkmark \quad$ MLVK approval of stage 2 arc welding. \\
\hline
\end{tabular}


INTERNATIONAL JOURNAL OF ACADEMIC RESEARCH IN BUSINESS AND SOCIAL SCIENCES

Vol. 9, No. 2, Feb, 2019, E-ISSN: 222 2-6990 @ 2019 HRMARS

P8

Welding lecturer of Polytechnic Malaysia

$>$ TIG welding expertise and safety

$>$ Experience of TIG welding for 16 years

$>$ Approvals and certificates in 36 and SMAW

$>$ The publication of tungsten inert gas arc welding books (GTSBN-978-96712450-03)

Assessment of the validity of the content of the instrument was made using the questionnaire of the contents of the instrument which required the assessor to provide the answer in the form of fivepoint scale namely: (1) strongly disagree, (2) disagree, (3) disagree, (4) agree and 5) Strongly agree. The data were analyzed using the method of calculating the validity of instrument content proposed by Tuckman and Waheed (1981). Tuckman and Waheed (1981) in Mohd Noah and Ahmad (2005) stated that expert judgments that exceed the $70 \%$ coefficient value have good content validity and have mastered a high level of achievement. Instruments with high content of validity will result in the achievement of the objectives that researchers want to measure (bt Yusof, R., \& bt Yusof, H., 2017). The formula for score assessment is as follows:

$\frac{\text { Expert Score Amount }}{\text { Maximum Score }} \times 100 \%=$ The achievement of the validity of the Content

\section{Data Analysis}

The findings of the validity study of teamwork instruments in the TIG welding training module consist of the overall content validity of the TIG Welding Training Modules based on the adaptation from the Student Activity Survey Form (UPM) (2011). As a result of an eight person expert assessment, the value of the content validity of the TIG Welding Training Module can be seen in Table 2 below: 
INTERNATIONAL JOURNAL OF ACADEMIC RESEARCH IN BUSINESS AND SOCIAL SCIENCES Vol. 9, No. 2, Feb, 2019, E-ISSN: $2222-6990$ ๑ 2019 HRMARS

Table 2: The validity of the instrument work tool as a whole by item TIG Welding Training Module

\begin{tabular}{|c|c|c|c|c|c|c|c|c|c|c|}
\hline \multirow[t]{2}{*}{ Item } & \multicolumn{8}{|c|}{ Content Specialist Validity } & \multirow[t]{2}{*}{ Average } & \multirow{2}{*}{$\begin{array}{l}\text { Expert } \\
\text { views }\end{array}$} \\
\hline & 1 & 2 & 3 & 4 & 5 & 6 & 7 & 8 & & \\
\hline $\begin{array}{l}\text { 19. Modul Latihan Kimpalan TIG membantu } \\
\text { saya berbincang secara terbuka dengan ahli } \\
\text { kumpulan. }\end{array}$ & 100 & 100 & 100 & 80 & 80 & 80 & 100 & 100 & 92.5 & Accept \\
\hline $\begin{array}{l}\text { 20. Modul Latihan Kimpalan TIG membantu } \\
\text { saya menerima cadangan daripada ahli } \\
\text { kumpulan secara terbuka. }\end{array}$ & 100 & 100 & 100 & 80 & 80 & 80 & 100 & 80 & 90 & Accept \\
\hline $\begin{array}{l}\text { 21. Modul Latihan Kimpalan TIG membantu } \\
\text { saya gemar berinteraksi dengan ahli kumpulan. }\end{array}$ & 100 & 100 & 100 & 80 & 80 & 100 & 100 & 100 & 95 & Accept \\
\hline $\begin{array}{l}\text { 22. Modul Latihan Kimpalan TIG membantu } \\
\text { saya mudah untuk menyesuaikan diri dengan } \\
\text { ahli kumpulan. }\end{array}$ & 100 & 100 & 100 & 80 & 80 & 80 & 100 & 80 & 90 & Accept \\
\hline $\begin{array}{l}\text { 23. Modul Latihan Kimpalan TIG membantu } \\
\text { saya memahami dengan jelas peranan saya } \\
\text { dalam kumpulan. }\end{array}$ & 100 & 100 & 100 & 80 & 80 & 100 & 100 & 80 & 92.5 & Accept \\
\hline $\begin{array}{l}\text { 24. Modul Latihan Kimpalan TIG membantu } \\
\text { saya melihat kepelbagaian dalam kalangan ahli } \\
\text { kumpulan sebagai satu kekuatan di dalam } \\
\text { menyelesaikan masalah. }\end{array}$ & 100 & 100 & 100 & 80 & 80 & 80 & 100 & 80 & 90 & Accept \\
\hline $\begin{array}{l}\text { 25. Modul Latihan Kimpalan TIG membantu } \\
\text { saya memimpin kumpulan jika diperlukan } \\
\text { untuk menyelesaikan masalah. }\end{array}$ & 100 & 100 & 100 & 80 & 80 & 80 & 100 & 80 & 90 & Accept \\
\hline $\begin{array}{l}\text { 26. Modul Latihan Kimpalan TIG membantu } \\
\text { saya mengutamakan pandangan ahli kumpulan } \\
\text { lebih utama daripada pandangan individu. }\end{array}$ & 100 & 100 & 100 & 80 & 80 & 80 & 100 & 80 & 90 & Accept \\
\hline $\begin{array}{l}\text { 27. Modul Latihan Kimpalan TIG membantu } \\
\text { saya menjadi pengikut yang efektif }\end{array}$ & 100 & 100 & 100 & 80 & 80 & 80 & 100 & 80 & 90 & Accept \\
\hline $\begin{array}{l}\text { 28. Modul Latihan Kimpalan TIG membantu } \\
\text { saya menjadikan matlamat kumpulan sebagai } \\
\text { matlamat diri dalam menyelesaikan masalah. }\end{array}$ & 100 & 100 & 100 & 80 & 100 & 100 & 100 & 80 & 95 & Accept \\
\hline $\begin{array}{l}\text { 29. Modul Latihan Kimpalan TIG membantu } \\
\text { saya memberi sumbangan kepada kejayaan } \\
\text { kumpulan. }\end{array}$ & 100 & 100 & 100 & 80 & 100 & 80 & 100 & 80 & 92.5 & Accept \\
\hline $\begin{array}{l}\text { 30. Modul Latihan Kimpalan TIG menolong } \\
\text { saya dalam membantu ahli kumpulan yang lain } \\
\text { untuk mencapai matlamat dengan jayanya. }\end{array}$ & 100 & 100 & 100 & 80 & 100 & 60 & 100 & 80 & 90 & Accept \\
\hline $\begin{array}{l}\text { 31. Modul Latihan Kimpalan TIG membantu } \\
\text { saya berasa bangga jika ahli kumpulan } \\
\text { mencapai kejayaan. }\end{array}$ & 100 & 100 & 100 & 80 & 100 & 80 & 100 & 80 & 92.5 & Accept \\
\hline
\end{tabular}

Based on Table 2, the overall percentages for each item in the questionnaire were more than $80 \%$. The researcher found that the lowest percentage was 90 percent for items 20, 22, 24, 25, 26, 27 and 30. While the highest percentage of content validity is 95 percent ie for items 21 and 28 , this content indicates that the validity of the content of the teamwork instrument in the TIG Welding Training Module is achieving high achievement levels. Hence, based on the average analysis of the total percentage value is $91.54 \%$ more than 70\%. Tuckman and Waheed (1981) in Mohd Noah and Ahmad (2005) stated that expert judgments that exceed the $70 \%$ coefficient value have good content validity and have mastered a high level of achievement. This means that the level of validity of teamwork 
instruments in the TIG Welding Training Module is reliable and has a strong consistency. In other words, the teamwork tool in the TIG Welding Training Modules based on Project Based Learning (PBP) is believed to improve the teamwork of Malaysian Polytechnic students. The expert panel's validity value is above .06 i.e. the minimum value set for acceptance.

\section{Conclusion}

The researcher developed a teamwork questionnaire instrument in the TIG Welding Training Module based on a specific and complete Project Based Learning (PBP) for Polytechnic Malaysia. The findings of the validity of the content of a team workforce demonstrate the contents of this instrument are valid and of good quality and can be applied. It is hoped that a teamwork workforce in TIG Welding Training Modules will enhance the achievement of polytechnic students in turn to create human capital that will become the catalyst for future development.

\section{References}

Anastasi, A. dan Urbina, S. (1997). Psychological testing (7th ed.). New Jersey: Prentice-Hall. Badarudin, I. M. (2010). Shape assignment by genetic algorithm towards designing optimal areas. International Journal of Computer Science, 7(4), 1-7.

Borang Soal Selidik Aktiviti Pelajar UPM (2011), Dokumen selepas Pelaksaan aktiviti, Borang mengikut keperluan prosedur pelaksanaan aktiviti oleh pelajar (muat turunhttp://www.hep.upm.edu.my) http://hep.upm.edu.my/upload/dokumen/20171202170754SLIDE_AKTIVITI.pdf

Yusof, R., \& Yusof, H. (2017). KESAHAN MODEL AMALAN KEPIMPINAN GURU. JuKu: Jurnal Kurikulum \& Pengajaran Asia Pasifik, 3(2), 1-11.

DiFonzo, F. L. (2010). Is Management Education Better Learned In Teams? A Studyof Teamwork within the Business Education Curriculum. Capella University:Thesis PhD.

IDRIS, I. (2012). Analisis pengaruh kualitas produk, harga, lokasi dan kualitas pelayanan terhadap keputusan pembelian (Studi pada waroeng spesial sambal cabang Tembalang,

Semarang) (Doctoral dissertation, Fakultas Ekonomika dan Bisnis).

Idris, N. (2013). Penyelidikan dalam pendidikan. McGraw-Hill Education.

Mohd Noah, S., \& Ahmad, J. (2005). Pembinaan modul: bagaimana membina modul latihan dan modul akademik. University Putra Malaysia.

Mohd Salleh, K., Sulaiman, N. L. \& Talib, K. N. (2010). Globalization's Impact on Soft Skills Demand in The Malaysian Workforce and Organizations: What Makes Graduates Employable? Proceedings of The UPI International Conference on Technical and Vocational Education and Training: Bandung: Universitas of Bandung. pp. 210-215.

Noor, M. A. (2010). Some iterative methods for solving nonlinear equations using homotopy perturbation method. International journal of computer Mathematics, 87(1), 141-149.

Othman, M. S., \& Kassim, A. Y. (2018). Kesahan dan Kebolehpercayaan Instrumen Komposisi Pengajaran Guru Pendidikan Islam Sekolah Rendah yang Mengintegrasikan Kemahiran Berfikir Aras Tinggi (KBAT) Menerusi Pengajaran Akidah. Sains Humanika, 10(3).

Pallant J. 2007. SPSS Survival Manual. Sydney: Ligare Book Printer. 
INTERNATIONAL JOURNAL OF ACADEMIC RESEARCH IN BUSINESS AND SOCIAL SCIENCES Vol. 9, No. 2, Feb, 2019, E-ISSN: 2222-6990 C 2019 HRMARS

Peslak. (2005). A Twelve Step Multiple Course Approach To Teaching Enterprise Resource Planing. Dicapai pada Mac 14, 2014 dari http://jise.edsigbh.org/Volume16/162/Pdf/V16N2P147-Abs.pdf

Sundrum, A., \& Kanasan, M. (2013). Students' perception on the effectiveness of teamwork based activities in enhancing the learning process. Eurasian Journal of Social Sciences, 1(2), 52-60.

Tuckman, B.W., \& Waheed, M.A. (1981). Evaluating an individualized science programmed for community college student. Journal of research in Science Teaching, 18, 489-495

Yulpisman, A. (2006). Modul Pembangunan Kemahiran Insaniah (Soft Skills) untuk Institusi Pengajian Tinggi Malaysia. Dicapai pada Mac 14, 2014 dari http://www.utusan.com.my/utusan/content 